\title{
The Caddo Ceramic Assemblage from the Hardin A Site (41GG69) on the Sabine River in Gregg County, Texas
}

Timothy K. Perttula

Heritage Research Center, Stephen F. Austin State University

Follow this and additional works at: https://scholarworks.sfasu.edu/ita

Part of the American Material Culture Commons, Archaeological Anthropology Commons, Environmental Studies Commons, Other American Studies Commons, Other Arts and Humanities Commons, Other History of Art, Architecture, and Archaeology Commons, and the United States History Commons

Tell us how this article helped you.

This Article is brought to you for free and open access by the Center for Regional Heritage Research at SFA ScholarWorks. It has been accepted for inclusion in Index of Texas Archaeology: Open Access Gray Literature from the Lone Star State by an authorized editor of SFA ScholarWorks. For more information, please contact cdsscholarworks@sfasu.edu. 
The Caddo Ceramic Assemblage from the Hardin A Site (41GG69) on the Sabine River in Gregg County, Texas

\section{Creative Commons License}

\section{(c) (1) \&}

This work is licensed under a Creative Commons Attribution-NonCommercial 4.0 International License 


\title{
The Caddo Ceramic Assemblage from the Hardin A Site (41GG69) on the Sabine River in Gregg County, Texas
}

\author{
Timothy K. Perttula
}

\section{INTRODUCTION}

The Hardin A site (41GG69) is an ancestral Caddo settlement on a high alluvial terrace landform overlooking the Sabine River floodplain in Gregg County, Texas, a few miles west of Longview, Texas (Figure 1). The modern channel of the river is ca. $650 \mathrm{~m}$ to the south. The site, which is in the East Texas Pineywoods, has well preserved midden deposits, pit features, as well as a looted cemetery area (Boyd and Perttula 2001).

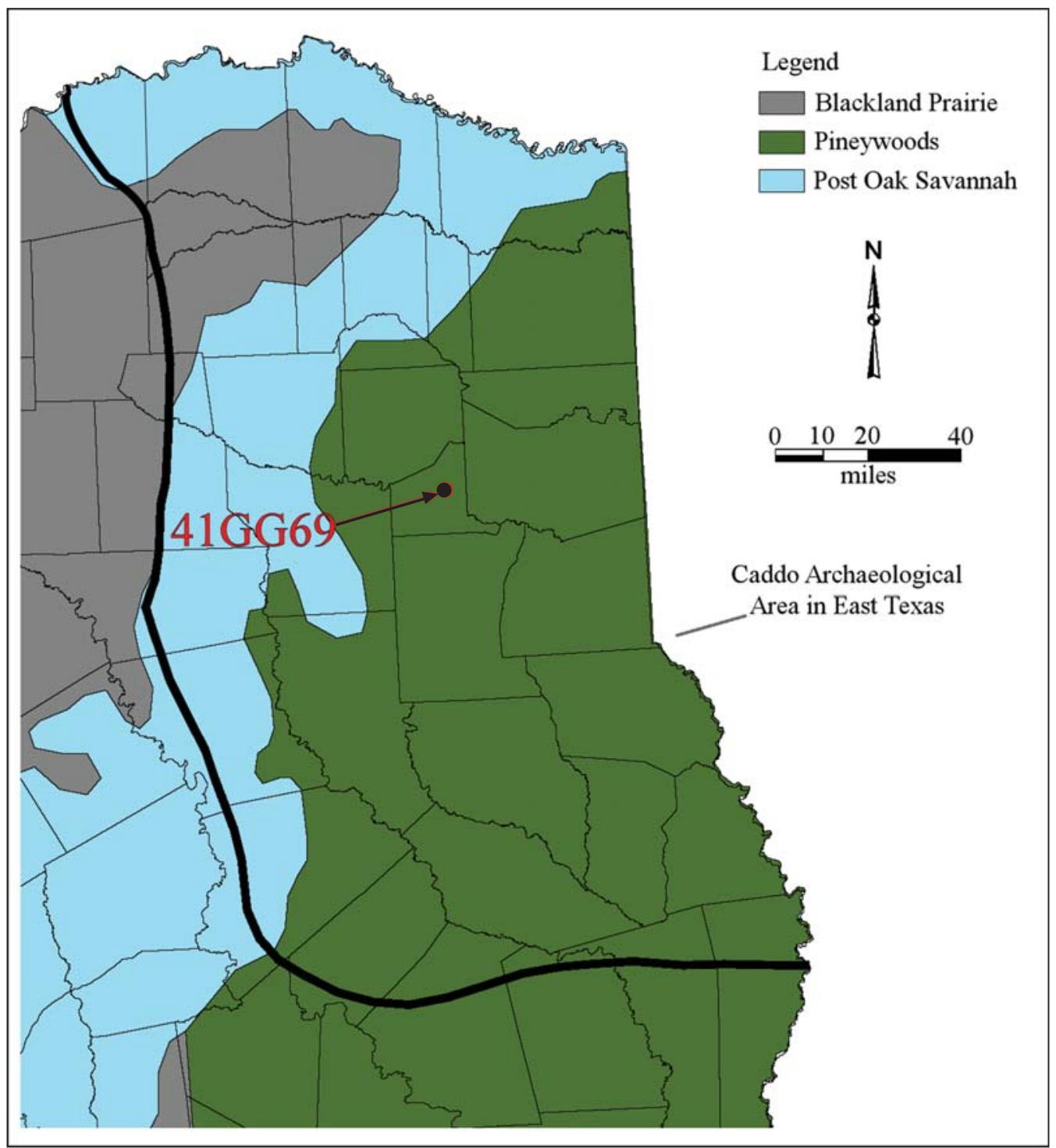

Figure 1. The location of the Hardin A site in the East Texas Pineywoods. 


\section{WORK CONDUCTED AT THE SITE}

The first work done at the site was the surface collection of artifacts in 1995, primarily the collection of ceramic sherds. The presence of mussel shells and animal bones in one area indicated that there were preserved midden deposits on the site.

Hand excavations (Unit 1, a 1 x 2 m unit) were completed in a known midden area (Boyd and Perttula 2001:Figure 1) by Bryan Boyd, with the assistance of Mark Walters, in the spring of 2000. That work exposed deep $(+90 \mathrm{~cm})$ archaeological deposits in a sandy loam soil with some buried and preserved midden deposits, as well as part of a large pit feature in the northern and eastern part of the unit. The pit feature (Feature

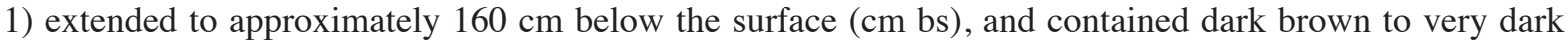
grayish-brown fill with large amounts of ceramics, animal bone (Schniebs 2014), and charred plant remains (especially hickory nutshells); it was probably an underground storage feature. Unit 2 was excavated in 2003.

\section{CADDO CERAMIC ASSEMBLAGE}

There is a substantial Caddo ceramic assemblage of sherds from plain wares, fine wares, and utility wares from the Hardin A site, gathered from both surface collections and hand excavations. The assemblage includes 1535 plain and 570 decorated utility ware and fine ware sherds from various contexts (Table 1); most of the sherds are from surface contexts ( 80 percent), with the remainder from the two excavation units. The plain to decorated sherd ratio of this assemblage is a moderate 2.69, consistent with other Early to Middle Caddo period ceramic assemblages in East Texas. There are also four long-stemmed Red River pipe sherds in the collection (see below).

Table 1. Provenience of ceramic sherds from the Hardin A site.

\begin{tabular}{lrccr}
\hline Provenience & Plain ware & Fine ware & Utility ware & N \\
\hline Surface, general & 663 & 12 & 42 & 717 \\
Surface, east side & 2 & - & - & 2 \\
Surface, west side & 119 & 13 & 78 & 210 \\
Surface, around Unit 1 & 5 & 14 & 73 & 92 \\
Surface, Area A & 462 & 32 & 172 & 666 \\
Unit 1 & 241 & 3 & 93 & 356 \\
Unit 2 & 43 & 96 & 474 & 2105 \\
\hline Totals & 1535 & &
\end{tabular}

The analysis of the recovered ceramic sherds from the Hardin A site emphasizes the acquisition of information on the stylistic and technological character of the ancestral Caddo ceramic assemblage. The stylistic analysis of the Hardin A site ceramics focuses on the definition of recognizable decorative elements in the fine wares (i.e., the engraved and red-slipped vessels, including carinated bowls and bottles) and utility wares (i.e., the coarse paste decorated vessels), usually cooking or storage jars and simple bowls. When sherds large enough to exhibit overall design motifs are present in the assemblage, typological classifications are possible.

The three wares are known to have been made and used differently, based on functional, technological, and stylistic analyses on numerous Caddo sherd assemblages in the broader East Texas region, with uses ranging from food service, cooking of food stuffs, as containers for liquids, and for plant food/seed crop storage (Perttula 2013). The ceramic analysis of these wares will be completed in 
conjunction with technological analyses of vessel sherds, emphasizing paste characteristics and nonplastic inclusions (i.e., temper).

\section{Plain Wares}

The plain wares include 62 rims, 1379 body sherds, and 94 base sherds (Table 2). The plain rims are from bowls, carinated bowls, jars, and bottles. The plain ware rims represent 40 percent of all the rim sherds from the site (see below), indicating that plain ware vessels were abundant in the Hardin A ceramic assemblage.

Table 2. Plain wares in the Hardin A ceramic assemblage.

\begin{tabular}{lcccc}
\hline Temper & Rim & Body & Base & N \\
\hline Grog & 52 & 1181 & $82^{*}$ & 1315 \\
Bone & 10 & 198 & 12 & 220 \\
\hline Totals & 62 & 1379 & 94 & 1535 \\
\hline
\end{tabular}

*includes one spindle whorl from Area A

The ancestral Caddo ceramic sherd assemblage at the Hardin A site is primarily grog-tempered, as 85.6 percent of the sherds are tempered with crushed sherds (Table 3). Only 14.4 percent of the sherds are from vessels tempered with burned bone, and there are no shell-tempered sherds in the assemblage. These proportions in temper use are consistent with other Middle Caddo period sites in this part of the Sabine River basin (Perttula and Nelson 2013:69-70). The limited use of bone temper at the Hardin A site and other Gregg County Middle Caddo sites (e.g., Perttula and Nelson 2013) in the manufacture of vessels stands in contrast to broadly contemporaneous sites in Harrison and Rusk counties in the Sabine River basin where the use of burned bone as a temper is much more common. This includes sherds from 41HS74 (20 percent with bone temper, Heartfield, Price, and Greene, Inc. 1988); 41HS573 (29 percent with bone temper and 21 percent with grog and bone, Gadus et al. 2006); 41HS574 (19.5 percent with bone temper and 16.5 percent with grog and bone, Gadus et al. 2006); 41HS588 (3.4 percent with bone temper and 35 percent with grog and bone, Dockall et al. 2008); 41HS844 (11 percent with bone temper and 25 percent with grog and bone, Gadus et al. 2006); 41HS846 (12 percent with bone temper and 16 percent with grog and bone); and 41RK557 (29 percent with bone temper and 22 percent with grog and bone, Dockall and Fields 2011). In general, these sites with considerable use of burned bone temper also have higher proportions of brushed sherds than do the Gregg County Middle Caddo sites.

Table 3. Use of temper in Hardin A ceramic assemblage.

\begin{tabular}{lcccr}
\hline Temper & Plain ware & Fine ware & Utility ware & N \\
\hline Grog & 1315 & 75 & 413 & 1803 \\
Bone & 220 & 21 & 61 & 302 \\
\hline Totals & 1535 & 96 & 474 & 2105 \\
\hline
\end{tabular}

The highest proportions of bone temper at the Hardin A site occur in the fine wares: 21.9 percent (see Table 3). By contrast, only 14.3 percent of the plain ware sherds and 12.9 percent of the utility ware sherds have bone temper inclusions. 


\section{Decorated Wares}

Decorative techniques present in the Hardin A ceramic sherd collections include engraving, incising, punctation, brushing, pinching, ridging, appliqué, and on certain sherds, combinations of decorative techniques (i.e., brushed-incised and brushed-punctated, or incised-punctated sherds) created the decorative elements and motifs. Engraving was done with a sharp tool when the vessel was either leather-hard or after it was fired, while the other decorative techniques were executed with tools or fingers (incising, punctations, and pinching with wood or bone sticks or dowels), by adding strips of clay to the wet body (appliqué), using frayed sticks or grass stems (brushing) across the vessel surface, or corrugating vessel coils when the vessel was wet or still plastic to create a series of neck bands. Excising is considered a form of engraved decoration, where the clay is deliberately and closely marked/scraped and carved away with a sharp tool, usually to create triangular elements or crescent-shaped elements separating or defining scrolls.

Ceramic style decorative methods and elements defined and recognized on sherds from the Hardin A site simply represent one classification of different ways of decorating a vessel by the prehistoric Caddo peoples, and there is general consensus that shared styles are "the result of direct cultural transmission once chance similarity in a context of limited possibilities is excluded" (Dunnell 1978:199). If the decorative elements are truly stylistic in character, they allow the measurement of time as well as interaction between different but contemporaneous groups of people, along with an assessment of a potter's place within a larger tradition of ceramic practice. Because the lion's share of the ceramics are sherds rather than vessels or sherd vessel groupings, the most accessible stylistic information from the Hardin A site is the rim and body decorations (often different on the same vessel).

\section{Utility Wares}

Utility ware sherds are from vessels used for cooking and storage tasks at the site, almost always jars. These vessels are more coarsely tempered, and have thicker and more durable walls than most of the fine wares. They often have extensive areas of charred organic residues and sooting from use over an open fire. Utility wares have wet paste decorations; that is, decorations executed before the vessel was fired or dried leather-hard.

Between 82-83 percent of the rim and body sherds from the Hardin A site are from utility wares; the remainder are from fine wares. Approximately 49 percent of all the rim sherds in the assemblage $(n=155)$ are from utility wares; accordingly, the utility wares are the principal ware at the site.

There are 14 different decorative methods represented in the utility ware rim and body sherds from the Hardin A site (Table 4). The decorative methods are all wet paste methods, meaning they were executed before the vessel was fired or was leather-hard. The principal utility ware decorative methods in the sherds are incised (29 percent), incised-punctated (26 percent), brushed (16 percent), and tool punctated (15 percent). Considering just the rim sherds, 8 percent are from brushed and brushed-punctated vessels; 37 percent are from incised vessels; 25 percent are rims from incised-punctated vessels; and 27 percent are from vessels with either circular, fingernail, or tool punctations on the rim.

\section{Appliqued}

The appliqued body sherds comprise only 0.4 percent of the utility wares from the Hardin A site (see Table 4). They include one body sherd with a straight appliqued ridge and another body sherd (Unit 1, 30-40 $\mathrm{cm}$ bs) with a straight appliqued fillet. 
Table 4. Decorative methods in utility wares from the Hardin site.

\begin{tabular}{|c|c|c|c|c|c|}
\hline \multirow[b]{2}{*}{ Decorative method } & \multicolumn{2}{|c|}{ Grog } & \multicolumn{2}{|c|}{ Bone } & \multirow[b]{2}{*}{$\mathrm{N}$} \\
\hline & rim & body & rim & body & \\
\hline Appliqued & - & 2 & - & - & 2 \\
\hline Appliqued-Incised & - & 1 & - & - & 1 \\
\hline Brushed & 3 & 50 & - & 23 & 76 \\
\hline Brushed-Incised & - & 14 & - & 4 & 18 \\
\hline Brushed-Incised-Punctated & - & 2 & - & - & 2 \\
\hline Brushed-Punctated & 3 & 7 & - & - & 10 \\
\hline Incised & 25 & 103 & 3 & 8 & 139 \\
\hline Incised-Punctated & 16 & 95 & 3 & 11 & 125 \\
\hline Pinched & - & 3 & - & - & 3 \\
\hline Punctated, cane & - & 1 & - & - & 1 \\
\hline Punctated, circular & 5 & 10 & - & 2 & 17 \\
\hline Punctated, fingernail & 2 & 6 & - & 1 & 9 \\
\hline Punctated, tool & 15 & 47 & 1 & 7 & 70 \\
\hline Ridged & - & 1 & - & - & 1 \\
\hline Totals & 69 & 342 & 7 & 56 & 474 \\
\hline
\end{tabular}

\section{Appliqued-Incised}

The one grog-tempered body sherd with an appliqued-incised decorative method (see Table 4) is from a 1995 surface collection. The sherd has a straight appliqued fillet and parallel incised lines on either side of the fillet, and may be from the body of a Pease Brushed-Incised jar.

\section{Brushed}

Sherds with brushed decorative elements, either as the sole decorative method, or in combination with incised, incised-punctated, or punctated elements, comprise 22.4 percent of the utility wares from the site (see Table 4). More than 71 percent of these sherds simply have brushing marks in various directions (Table 5). These are from jars with either horizontal or diagonal brushing on the rim and likely with vertical (i.e., parallel brushed sherds whose orientation is not certain), opposed, or overlapping brushed marks on the vessel body. These sherds are likely from either Bullard Brushed or Pease Brushed-Incised vessels.

\section{Brushed-Incised}

The brushed-incised sherds fall into two categories: (1) body sherds with parallel brushing marks and parallel incised lines; the brushing marks and incised lines are probably oriented vertically on the body of Pease Brushed-Incised jars; and (2) parallel brushed body sherds that have either opposed or parallel incised lines overlying and drawn through the brushing (see Table 5). 
Table 5. Decorative elements on Brushed, Brushed-Incised, Brushed-Incised-Punctated, and Brushed-Punctated sherds.

\begin{tabular}{|c|c|c|c|}
\hline Decorative element & $\operatorname{Rim}$ & Body & $\mathrm{N}$ \\
\hline \multicolumn{4}{|l|}{ Brushed } \\
\hline diagonal brushed & 1 & - & 1 \\
\hline horizontal brushed & 2 & - & 2 \\
\hline opposed brushed & - & 1 & 1 \\
\hline overlapping brushed & - & 1 & 1 \\
\hline parallel brushed & - & 71 & 71 \\
\hline \multicolumn{4}{|l|}{ Brushed-Incised } \\
\hline parallel brushed-incised & - & 13 & 13 \\
\hline $\begin{array}{l}\text { parallel brushed and overlying opposed } \\
\text { incised lines }\end{array}$ & - & 2 & 2 \\
\hline $\begin{array}{l}\text { parallel brushed and overlying } \\
\text { parallel incised lines }\end{array}$ & - & 3 & 3 \\
\hline \multicolumn{4}{|l|}{ Brushed-Incised-Punctated } \\
\hline $\begin{array}{l}\text { horizontal brushed on rim and body, } \\
\text { tool punctated row at rim-body } \\
\text { juncture, and diagonal incised lines } \\
\text { over brushing on body }\end{array}$ & - & 1 & 1 \\
\hline $\begin{array}{l}\text { fingernail punctated row at rim-body } \\
\text { juncture, vertical brushed body, and } \\
\text { overlying diagonal incised lines } \\
\text { on body }\end{array}$ & - & 1 & 1 \\
\hline \multicolumn{4}{|l|}{ Brushed-Punctated } \\
\hline $\begin{array}{l}\text { diagonal brushed and tool punctated } \\
\text { row under the lip }\end{array}$ & 1 & - & 1 \\
\hline $\begin{array}{l}\text { diagonal brushed and diagonal tool } \\
\text { punctated row through brushing }\end{array}$ & 1 & - & 1 \\
\hline $\begin{array}{l}\text { horizontal brushed with tool punctated } \\
\text { row through the brushing }\end{array}$ & 1 & - & 1 \\
\hline $\begin{array}{l}\text { parallel brushed and adjacent tool } \\
\text { punctated row }\end{array}$ & - & 4 & 4 \\
\hline $\begin{array}{l}\text { parallel brushed and tool punctated row } \\
\text { through the brushing }\end{array}$ & - & 1 & 1 \\
\hline $\begin{array}{l}\text { vertical brushed below tool punctated } \\
\text { row }\end{array}$ & - & 1 & 1 \\
\hline $\begin{array}{l}\text { vertical brushed on either side of } \\
\text { vertical tool punctated row/zone }\end{array}$ & - & 1 & 1 \\
\hline Totals & 6 & 100 & 106 \\
\hline
\end{tabular}




\section{Brushed-Incised-Punctated}

Both brushed-incised-punctated lower rim-body sherds are from Unit 1 (110-130 cm bs and 130-140 $\mathrm{cm} \mathrm{bs}$ ), but they are from different vessels. The first lower rim-body sherd has horizontal brushed marks on either side of a row of tool punctations at the rim-body juncture, and a set of diagonal incised lines have been executed over the brushing marks on the vessel body (Figure $2 b$ ).

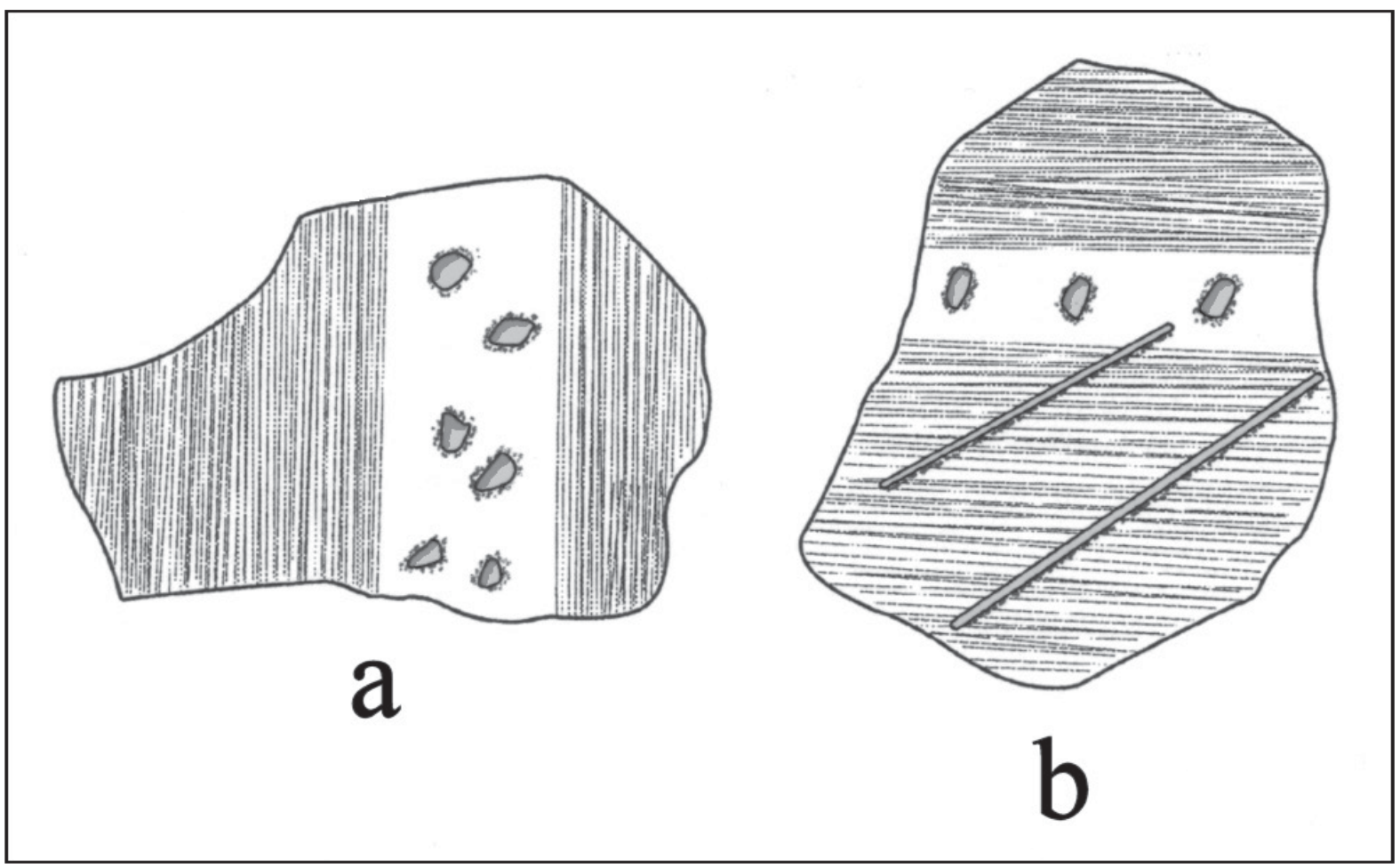

Figure 2. Decorative elements on brushed-punctated and brushed-incised-punctated body sherds. Provenience: a, General, 1995; b, Unit 1, 110-130 cm bs.

\section{Brushed-Punctated}

The brushed-punctated sherds are likely all from Pease Brushed-Incised jars (Suhm and Jelks 1962:119 and Plate 60). One rim has a row of tool punctates below the vessel lip and the remainder of the rim is covered with diagonal brushing marks (see Table 5). The other rims have tool punctated rows pushed through either diagonal or horizontal brushed decorative elements.

One of the brushed-punctated body sherds has parallel brushing marks with a row of tool punctations pushed through it. Five other body sherds have a row of tool punctations (probably at the rim-body juncture) adjacent to an area with either parallel or vertical brushing marks on the body of utility ware jars (see Table 5). The last brushed-punctated body sherd has areas of vertical brushing on either side of an open zone filled with tool punctations (see Figure 2a).

\section{Incised}

Sherds from incised vessels represent the most common utility ware in the Hardin A ceramic assemblage. They comprise 29 percent of the utility wares (see Table 4). Based on the rim sherds (Table 6), the principal incised decorative elements are diagonal lines (64 percent of the rims) - with the diagonal lines oriented either left to right or right to left-horizontal lines, horizontal and diagonal lines, or cross-hatched 
lines. These rims are likely from Canton Incised, Davis Incised, and Dunkin Incised jars; the vertical incised rim is also probably from a Dunkin Incised vessel (see Suhm and Jelks 1962:Plate 19d). Other likely rim decorative elements include diagonal opposed or chevron elements and horizontal and cross-hatched lines (Figure 3a), also from Dunkin Incised vessels.

Table 6. Decorative elements on Incised sherds.

\begin{tabular}{|c|c|c|c|}
\hline Decorative element & $\operatorname{Rim}$ & Body & $\mathrm{N}$ \\
\hline cross-hatched lines & 3 & 9 & 12 \\
\hline curvilinear lines & - & 4 & 4 \\
\hline diagonal lines & - & 1 & 1 \\
\hline diagonal lines, L [top] to $\mathrm{R}$ [bottom] & 6 & - & 6 \\
\hline diagonal lines, R [top] to L [bottom] & 12 & - & 12 \\
\hline diagonal opposed lines & 1 & 7 & 8 \\
\hline horizontal lines & 1 & 1 & 2 \\
\hline horizontal line under lip & 2 & - & 2 \\
\hline horizontal and cross-hatched lines & - & 2 & 2 \\
\hline horizontal and diagonal lines & 2 & 19 & 21 \\
\hline horizontal and diagonal hatched lines & - & 3 & 3 \\
\hline opposed lines & - & 3 & 3 \\
\hline parallel lines & - & 33 & 33 \\
\hline straight line & - & 28 & 28 \\
\hline vertical lines & 1 & - & 1 \\
\hline vertical hatched zones & - & 1 & 1 \\
\hline Totals & 28 & 111 & 139 \\
\hline
\end{tabular}

$\mathrm{R}=$ right; $\mathrm{L}=$ left

One body sherd (or the lower part of the rim of a utility ware jar) has vertical incised zones filled with hatched incised lines oriented in opposite directions (see Figure $3 b$ ). The remainder of the body sherds feature geometric or straight line elements, except for four body sherds with curvilinear incised lines (see Table 6).

\section{Incised-Punctated}

The sherds with incised-punctated decorative elements are the most stylistically diverse of all the utility wares from the Hardin A site (Table 7). The incised-punctated rim and body sherds comprise approximately 26.4 percent of the utility ware ceramic assemblage (see Table 4). Regardless of the specific combination of incised and punctated elements and motifs identified in the incised-punctated sherd assemblage, most of the motifs and elements are characterized by tool punctations (72 percent); 16 percent of the incised-punctated rim and body sherds have circular punctated elements; and the remaining 12 percent have fingernail punctated elements. 


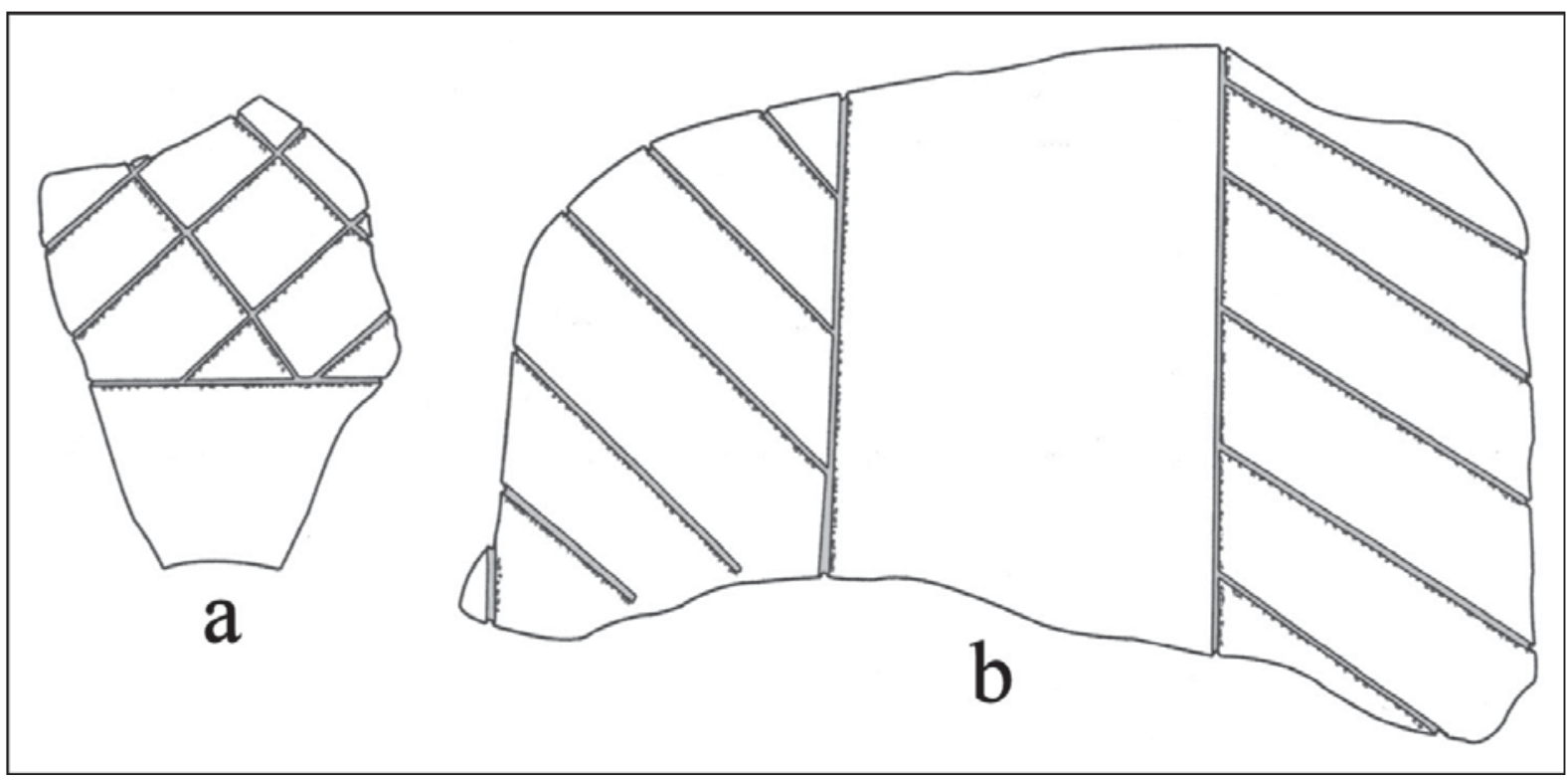

Figure 3. Decorative elements on incised body sherds. Provenience: a, Unit 1, 90-100 cm bs; b, area around Unit 1.

Table 7. Decorative elements on Incised-Punctated sherds.

\begin{tabular}{|c|c|c|c|}
\hline Decorative method & rim & body & $\mathrm{N}$ \\
\hline $\begin{array}{l}\text { circular incised zone filled with tool } \\
\text { punctates }\end{array}$ & - & 1 & 1 \\
\hline $\begin{array}{l}\text { circular and curvilinear zones filled } \\
\text { with tool punctates }\end{array}$ & 1 & - & 1 \\
\hline cross-hatched lines and single circular punctate & - & 1 & 1 \\
\hline $\begin{array}{l}\text { cross-hatched lines and triangle incised } \\
\text { zones filled with tool punctates }\end{array}$ & - & 2 & 2 \\
\hline $\begin{array}{l}\text { curvilinear incised line and adjacent } \\
\text { fingernail punctated zone }\end{array}$ & - & 1 & 1 \\
\hline $\begin{array}{l}\text { curvilinear incised line and adjacent } \\
\text { tool punctated zone/zones }\end{array}$ & - & 2 & 2 \\
\hline $\begin{array}{l}\text { curvilinear incised zone filled with } \\
\text { circular punctates }\end{array}$ & 1 & 5 & 6 \\
\hline $\begin{array}{l}\text { curvilinear incised zone filled with } \\
\text { fingernail punctates }\end{array}$ & - & 2 & 2 \\
\hline $\begin{array}{l}\text { curvilinear incised zone filled with } \\
\text { tool punctates }\end{array}$ & 1 & 6 & 7 \\
\hline $\begin{array}{l}\text { curvilinear zone filled with tool } \\
\text { punctates; tool punctated row also } \\
\text { outside of curvilinear zone }\end{array}$ & - & 1 & 1 \\
\hline $\begin{array}{l}\text { curvilinear and semi-circular incised } \\
\text { zones filled with tool punctates }\end{array}$ & 1 & 6 & 7 \\
\hline
\end{tabular}


Table 7. Decorative elements on Incised-Punctated sherds, cont.

\begin{tabular}{|c|c|c|c|}
\hline Decorative method & rim & body & $\mathrm{N}$ \\
\hline $\begin{array}{l}\text { curvilinear and semi-circular incised } \\
\text { zones filled with tool punctates; } \\
\text { adjacent set of vertical incised lines }\end{array}$ & - & 1 & 1 \\
\hline $\begin{array}{l}\text { curvilinear and triangular incised } \\
\text { zones filled with tool punctates }\end{array}$ & - & 1 & 1 \\
\hline $\begin{array}{l}\text { diagonal line and adjacent tool punctated } \\
\text { row/rows }\end{array}$ & - & 3 & 3 \\
\hline $\begin{array}{l}\text { diagonal line, } \mathrm{R} \text { [top] to } \mathrm{L} \text { [bottom] and } \\
\text { tool punctated row under the lip }\end{array}$ & 1 & - & 1 \\
\hline $\begin{array}{l}\text { diagonal lines }[R \text { to } L] \text { and fingernail } \\
\text { punctated row under lip }\end{array}$ & 1 & - & 1 \\
\hline $\begin{array}{l}\text { diagonal line }[\mathrm{R} \text { to } \mathrm{L}] \text { and incised triangle } \\
\text { filled with tool punctations }\end{array}$ & 2 & - & 2 \\
\hline $\begin{array}{l}\text { diagonal lines }[R \text { to } L \text { and } L \text { to } R] \text { and } \\
\text { incised triangles filled with tool punctates }\end{array}$ & $1^{*}$ & - & 1 \\
\hline $\begin{array}{l}\text { diagonal lines }[\mathrm{L} \text { to } \mathrm{R}] \text { and fingernail } \\
\text { punctated row at rim-body juncture }\end{array}$ & - & 1 & 1 \\
\hline $\begin{array}{l}\text { diagonal lines }[\mathrm{L} \text { to } \mathrm{R}] \text { separated by } \\
\text { fingernail punctated row; another } \\
\text { row at rim-body juncture }\end{array}$ & - & 4 & 4 \\
\hline $\begin{array}{l}\text { diagonal incised zones filled with cross- } \\
\text { hatched lines; fingernail punctated } \\
\text { row at rim-body juncture }\end{array}$ & - & 1 & 1 \\
\hline $\begin{array}{l}\text { diagonal incised zone filled with } \\
\text { fingernail punctates }\end{array}$ & - & 1 & 1 \\
\hline $\begin{array}{l}\text { diagonal incised zones filled with } \\
\text { circular punctates }\end{array}$ & 2 & - & 2 \\
\hline $\begin{array}{l}\text { diagonal incised zones filled with } \\
\text { tool punctates }\end{array}$ & - & 1 & 1 \\
\hline $\begin{array}{l}\text { diagonal and curvilinear lines and } \\
\text { curvilinear zone filled with } \\
\text { circular punctates }\end{array}$ & - & 1 & 1 \\
\hline $\begin{array}{l}\text { diagonal opposed lines and vertical tool } \\
\text { punctated row }\end{array}$ & - & 2 & 2 \\
\hline $\begin{array}{l}\text { diagonal opposed lines/zones separated by } \\
\text { tool punctated row }\end{array}$ & - & 1 & 1 \\
\hline $\begin{array}{l}\text { horizontal lines and tool punctated row } \\
\text { under the lip }\end{array}$ & 2 & - & 2 \\
\hline $\begin{array}{l}\text { horizontal incised line and adjacent } \\
\text { tool punctated row }\end{array}$ & - & 1 & 1 \\
\hline
\end{tabular}


Table 7. Decorative elements on Incised-Punctated sherds, cont.

\begin{tabular}{|c|c|c|c|}
\hline Decorative method & rim & body & $\mathrm{N}$ \\
\hline $\begin{array}{l}\text { horizontal and diagonal lines and } \\
\text { adjacent circular punctated row }\end{array}$ & - & 1 & 1 \\
\hline $\begin{array}{l}\text { horizontal and diagonal lines and } \\
\text { triangles filled with tool punctates }\end{array}$ & 1 & - & 1 \\
\hline $\begin{array}{l}\text { parallel incised lines and adjacent } \\
\text { fingernail punctated rows }\end{array}$ & - & 1 & 1 \\
\hline $\begin{array}{l}\text { parallel incised lines and adjacent tool } \\
\text { punctated rows }\end{array}$ & - & 1 & 1 \\
\hline $\begin{array}{l}\text { parallel incised zone filled with } \\
\text { circular punctations }\end{array}$ & - & 1 & 1 \\
\hline $\begin{array}{l}\text { parallel incised zone filled with tool } \\
\text { punctations }\end{array}$ & - & 1 & 1 \\
\hline $\begin{array}{l}\text { straight incised line and adjacent circular } \\
\text { punctated zone }\end{array}$ & - & 6 & 6 \\
\hline $\begin{array}{l}\text { straight incised line and adjacent fingernail } \\
\text { punctated zone }\end{array}$ & - & 2 & 2 \\
\hline $\begin{array}{l}\text { straight incised line and adjacent tool } \\
\text { punctated zones }\end{array}$ & - & 2 & 2 \\
\hline $\begin{array}{l}\text { straight incised line and adjacent tool } \\
\text { punctated zone }\end{array}$ & - & 32 & 32 \\
\hline $\begin{array}{l}\text { triangle incised zones filled with tool } \\
\text { punctates }\end{array}$ & - & 2 & 2 \\
\hline $\begin{array}{l}\text { triangle incised zone filled with tool } \\
\text { punctates }\end{array}$ & 3 & 11 & 14 \\
\hline $\begin{array}{l}\text { triangle incised zone filled with } \\
\text { circular punctates }\end{array}$ & 1 & 1 & 2 \\
\hline $\begin{array}{l}\text { vertical incised line and fingernail } \\
\text { punctated row under lip }\end{array}$ & 1 & - & 1 \\
\hline Totals & 19 & 106 & 125 \\
\hline
\end{tabular}

*rim is also lip notched; $\mathrm{R}=$ right; $\mathrm{L}=\mathrm{left}$

Most of the incised-punctated rim and body sherds are characterized by curvilinear, diagonal, triangular, and straight incised lines and zones either filled with circular, fingernail, or tool punctations, or the punctations are in undefined zones adjacent to the incised line elements (either curvilinear, diagonal, horizontal, or straight lines); only 1.6 percent of the sherds have circular incised-punctated elements and only 2.4 percent of the incised-punctated sherds have cross-hatched incised lines and punctated elements (see Table 7). Several of the rims and body sherds closely resemble a number of distinctive Canton Incised, Crockett Curvilinear Incised (Figures 4a-b, $f$ and 5a), and Pennington Punctated-Incised (Figures 4c-e, g and 5c) vessel motifs (see Suhm and Jelks 1962:Plates 12, 17, and 61). 


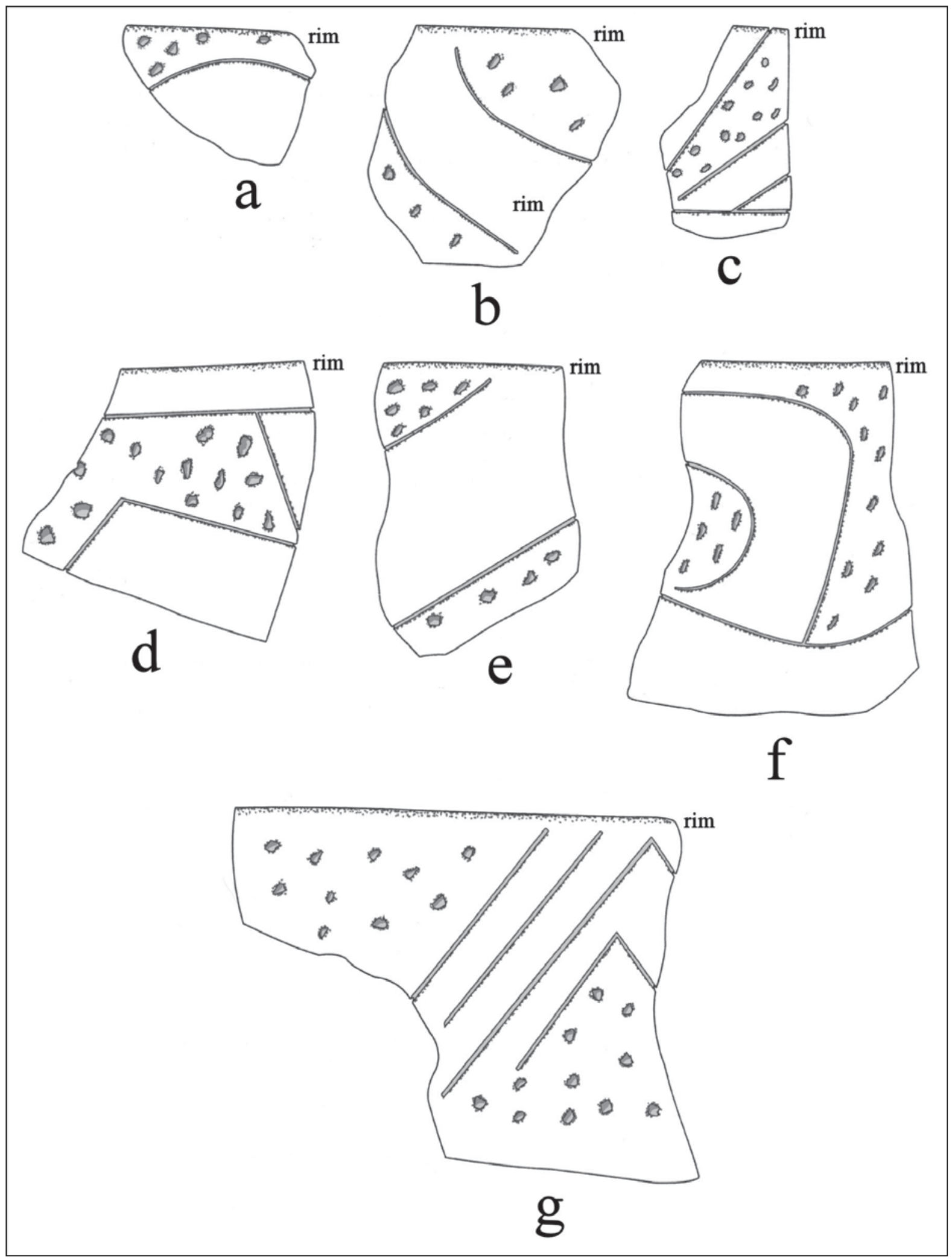

Figure 4. Decorative elements on incised-punctated rim sherds: a-b, west side, surface; c, General, Area A; d, Unit 1, 90-100 cm bs; e-g, area around Unit 1. 


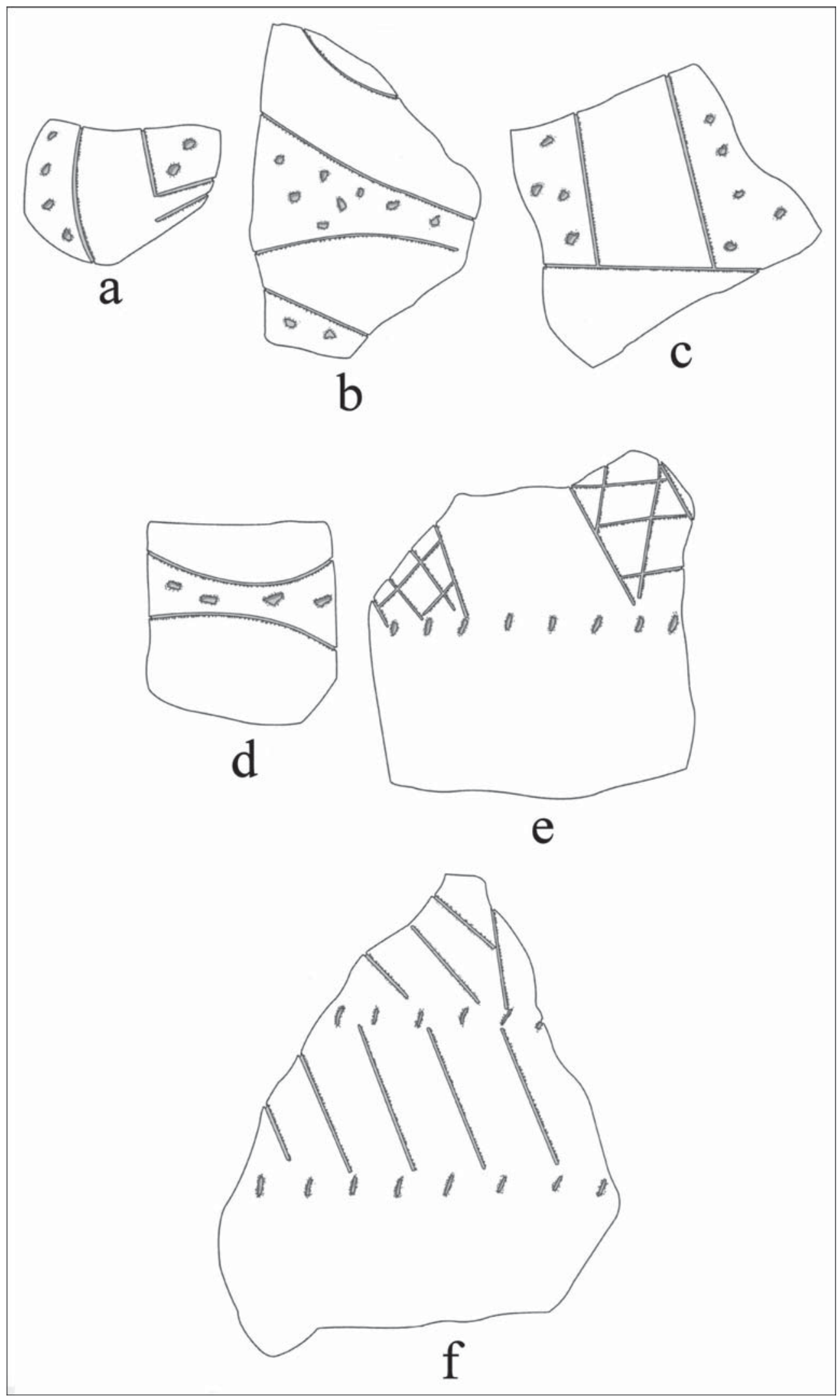

Figure 5. Decorative elements on incised-punctated body sherds: a, Area A, 1995; b, Unit 1, 50-60 cm bs; c, Unit 1, 60-70 cm bs; d-f, area around Unit 1 . 
Table 8. Decorative elements on cane, circular, fingernail, and tool punctated sherds.

\begin{tabular}{lccc}
\hline Decorative element & Rim & Body & N \\
\hline Punctated, cane & - & 1 & 1 \\
parallel row & & & \\
& 1 & 7 & 1 \\
Punctated, circular & 2 & 1 & 1 \\
circular punctated row under lip & - & 4 & 4 \\
circular punctated rows & - & - & 2 \\
single circular punctate & 2 & & 8 \\
small circular punctated rows & & 7 & 1 \\
small circular punctations, random & 1 & - & \\
& 1 & & 1 \\
Punctated, fingernail & & - & 76 \\
fingernail punctated rows & 1 & 1 & 7 \\
diagonal punctated rows & - & 7 & 97 \\
Punctated, tool & - & 74 & \\
diagonal punctated rows & & & \\
horizontal punctated rows & & & \\
punctated rows & 23 & & \\
single tool punctate & & & \\
\hline Totals & & & \\
\hline
\end{tabular}

There are other body sherds that have distinctive curvilinear zones filled with punctates, but the overall decorative motif is not defined (see Figure 5b-d). Other incised-punctated rim/lower rim-body sherds have a punctated row at the rim-body juncture (see Figure $5 \mathrm{e}-\mathrm{f}$ ). These are accompanied by diagonal incised lines, sets of stacked diagonal incised lines, and diagonal incised zones filled with cross-hatched lines (see Table 7).

\section{Pinched}

The three pinched body sherds comprise only 0.6 percent of the utility wares in the Hardin A decorated sherd ceramic assemblage (see Table 4). The sherds have parallel pinched rows $(\mathrm{n}=2$, Unit 2, 20-30 $\mathrm{cm}$ bs and General, Area A) or a single straight pinched row (General, Area A). These sherds are likely from Killough Pinched jars.

\section{Punctated, cane}

Cane, circular, fingernail, and tool punctated sherds represent a significant portion of the utility wares from the Hardin A site, comprising 20.5 percent of the utility ware sherd assemblage (see Table 4). These are from typologically undefined East Texas utility wares (cf. Suhm and Jelks 1962:159). Most of these sherds (72 percent) have tool punctations (Table 8). The one cane punctated sherd in the utility wares is from a surface collection in the area around Unit 1 . The body sherd has a single row of punctations executed with the cut end of a piece of cane. 


\section{Punctated, circular}

Sherds with circular punctations (17.5 percent of the punctated sherds) have rows of punctations of various sizes on vessel rims, beginning under the lip, as well as other rims that have randomly placed small circular punctations (see Table 8).

\section{Punctated, fingernail}

Fingernail punctated rim and body sherds primarily have rows of fingernail punctations on the rim and/ or body of utility ware jars. One rim has diagonal rows of fingernail punctations (see Table 8).

Punctated, tool

More than 93 percent of the rim sherds with tool punctations have horizontal rows of punctates around the vessel rim (see Table 8). One rim has diagonal rows of tool punctations.

Ridged

The one ridged sherd (from Area A) in the utility wares is from a grog-tempered Belcher Ridged, var. Belcher jar. Such jars were made principally by post-A.D. 1500 Belcher phase Caddo communities on the Red River in Northwest Louisiana (see Girard 2007), but there is one locale along the Sabine River in the Toledo Bend Reservoir area in East Texas and western Louisiana where ridged pottery is relatively common in decorated sherd assemblages (Perttula 2015:Table 6).

\section{Fine Wares}

Sherds from fine ware vessels are not particularly common in the Hardin A ceramic assemblage. Approximately 11 percent of all the rim sherds in the assemblage are from fine ware vessels, and only 17 percent of all the decorated sherds are from fine wares.

The fine ware sherds from the Hardin A site include sherds from vessels that have engraved and engravedappliqued decorations (Table 9). Also included in the fine wares are red-slipped sherds, as these primarily are from bowls, bottles, and carinated bowls, typical fine ware vessel forms, rather than from jars.

Table 9. Decorative methods in fine wares from the Hardin A site.

\begin{tabular}{lccccr}
\hline & \multicolumn{2}{c}{ Grog } & \multicolumn{2}{c}{ Bone } & N \\
Decorative method & rim & body & rim & body & 92 \\
\hline Engraved & 13 & 58 & 4 & 17 & 1 \\
Engraved-Appliqued & - & 1 & - & - & 3 \\
Red-slipped & - & 3 & - & - & 96 \\
\hline Totals & 13 & 62 & 4 & 17 & \\
\hline
\end{tabular}


Engraved

Sherds from bowls, carinated bowls, and bottles are represented in the engraved fine wares from the Hardin A site (Table 10). Engraved bowl and carinated bowls are the most common, accounting for 76 percent of the engraved sherds in the assemblage.

Table 10. Decorative elements on engraved sherds from the Hardin A site.

\begin{tabular}{|c|c|c|c|}
\hline Decorative element & Rim & Body & $\mathrm{N}$ \\
\hline \multicolumn{4}{|l|}{ Engraved bowl and carinated bowl } \\
\hline circular cross-hatched element & - & 1 & 1 \\
\hline concentric circles & - & 1 & 1 \\
\hline cross-hatched lines & - & 2 & 2 \\
\hline curvilinear lines & - & 12 & 12 \\
\hline diagonal lines & - & 1 & 1 \\
\hline diagonal lines, $\mathrm{L}$ to $\mathrm{R}$ & $2 *$ & - & 2 \\
\hline diagonal opposed lines & 1 & 1 & 2 \\
\hline $\begin{array}{l}\text { diagonal opposed lines and hatched } \\
\text { diagonal zone }\end{array}$ & 1 & - & 1 \\
\hline hatched zone & - & 1 & 1 \\
\hline $\begin{array}{l}\text { hatched diagonal zone and vertical } \\
\text { hatched zone }\end{array}$ & - & 1 & 1 \\
\hline hatched semi-circle element & - & 2 & 2 \\
\hline horizontal lines & 3 & 3 & 6 \\
\hline horizontal and cross-hatched lines & - & 1 & 1 \\
\hline horizontal and curvilinear lines & 1 & 1 & 2 \\
\hline $\begin{array}{l}\text { horizontal, curvilinear, and open } \\
\text { triangle elements }\end{array}$ & 1 & - & 1 \\
\hline horizontal and diagonal lines & - & 5 & 5 \\
\hline horizontal and diagonal opposed lines & 1 & - & 1 \\
\hline horizontal and semi-circular lines & 1 & - & 1 \\
\hline $\begin{array}{l}\text { horizontal line and cross-hatched } \\
\text { curvilinear zone }\end{array}$ & - & 1 & 1 \\
\hline $\begin{array}{l}\text { horizontal line and vertical zone with } \\
\text { horizontal hatched lines }\end{array}$ & - & 1 & 1 \\
\hline horizontal hatched zones & 1 & - & 1 \\
\hline horizontal cross-hatched zone & 1 & 2 & 3 \\
\hline parallel lines & - & 9 & 9 \\
\hline $\begin{array}{l}\text { parallel lines ending in excised } \\
\text { triangles }\end{array}$ & - & 1 & 1 \\
\hline
\end{tabular}


Table 10. Decorative elements on engraved sherds from the Hardin A site, cont.

\begin{tabular}{|c|c|c|c|}
\hline Decorative element & Rim & Body & $\mathrm{N}$ \\
\hline semi-circular lines & 1 & - & 1 \\
\hline straight line & - & 9 & 9 \\
\hline vertical line and diagonal opposed lines & - & 1 & 1 \\
\hline $\begin{array}{l}\text { Subtotal, bowl and carinated } \\
\text { bowl sherds }\end{array}$ & 14 & 56 & 70 \\
\hline \multicolumn{4}{|l|}{ Engraved bottle } \\
\hline $\begin{array}{l}\text { circle element with cross-hatched and } \\
\text { hatched zones }\end{array}$ & - & 1 & 1 \\
\hline curvilinear lines & - & 3 & 3 \\
\hline $\begin{array}{l}\text { curvilinear line with small excised } \\
\text { triangles }\end{array}$ & - & 1 & 1 \\
\hline curvilinear hatched zone & - & 1 & 1 \\
\hline diagonal opposed curvilinear lines & - & 2 & 2 \\
\hline diagonal opposed lines & - & 1 & 1 \\
\hline hatched zone and open triangle & - & 1 & 1 \\
\hline horizontal lines & 3 & 1 & 4 \\
\hline $\begin{array}{l}\text { horizontal line and narrow diagonal } \\
\text { hatched zone }\end{array}$ & - & 1 & 1 \\
\hline $\begin{array}{l}\text { horizontal line and cross-hatched } \\
\text { triangle }\end{array}$ & - & 1 & 1 \\
\hline $\begin{array}{l}\text { horizontal lines and hatched pendant } \\
\text { triangles }\end{array}$ & - & 1 & 1 \\
\hline $\begin{array}{l}\text { horizontal line, hatched triangle, and } \\
\text { curvilinear hatched zone }\end{array}$ & - & 1 & 1 \\
\hline parallel lines & - & 2 & 2 \\
\hline straight line & - & 2 & 2 \\
\hline Subtotal, engraved bottle sherds & 3 & 19 & 22 \\
\hline Totals & 17 & 75 & 92 \\
\hline
\end{tabular}

*one rim also has diagonal engraved lines on the lip itself

\section{Engraved sherds from bowls and carinated bowls}

The rim sherds from fine ware bowls and carinated bowls include several distinct decorative elements (see Table 10). They include rims with sets of horizontal lines (21 percent of the rims), probably from Hickory Engraved vessels, diagonal and diagonal opposed lines (Figure 6a, c, 36 percent of the rims), horizontal and 
diagonal lines (7 percent, possibly from Holly Fine Engraved vessels, although the rim lacks the excised areas seen on Holly Fine Engraved examples, see [Suhm and Jelks 1962:Plate 39]), horizontal lines with associated hatched or cross-hatched zones (Figure 6b, d-e, 14 percent), and several rims (29 percent) with either semi-circular lines, horizontal and curvilinear elements (Figure 6f), or horizontal and semi-circular elements. Most of these sherds are typologically unidentified.

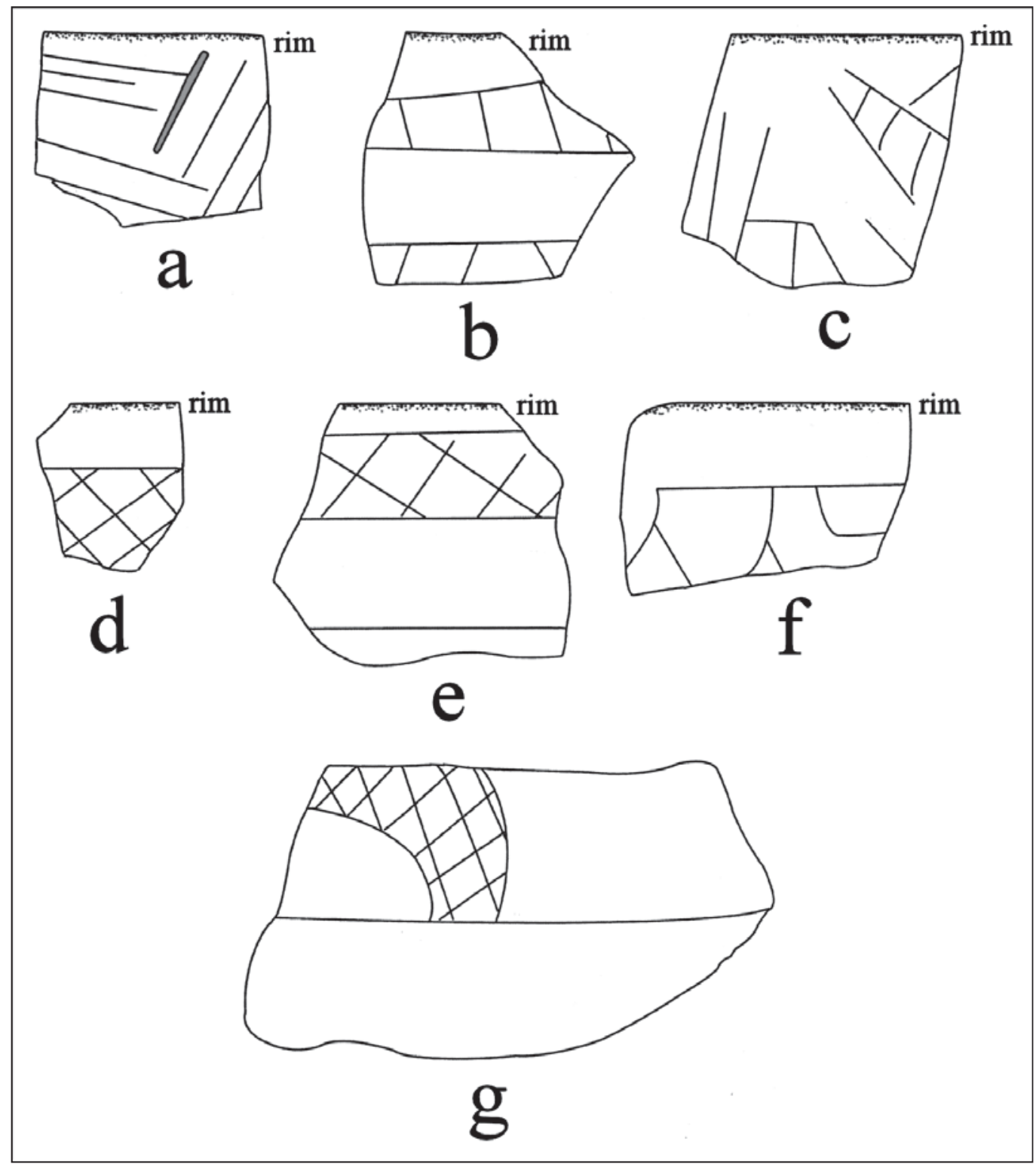

Figure 6. Decorative elements on engraved rim and body sherds. Provenience: a, west side, surface; b-e, General, Area A; f, Unit 1, 40-50 cm bs; g, area around Unit 1.

Body sherds from bowls and carinated bowls have the same range of decorative element, with the notable exception of one body sherd with a horizontal line and a curvilinear cross-hatched zone (see Figure 6g). Other important decorative elements on fine ware body sherds include those with sets of curvilinear lines, narrow hatched zones, and hatched semi-circles (see Table 10).

Combined, the most common decorative elements in the engraved rim and body sherds include sets of curvilinear lines (17 percent) and horizontal lines in association with cross-hatched, curvilinear, diagonal, 
diagonal opposed, and semi-circular lines (16 percent) (see Table 10). Other important elements include sets of parallel engraved lines (14 percent), probably either horizontal or diagonal in orientation), diagonal and diagonal opposed lines ( 9 percent), sets of horizontal lines ( 9 percent), and horizontal lines in association with hatched or cross-hatched zones (9 percent) (see Table 10).

\section{Engraved bottle sherds}

About 24 percent of the engraved sherds in the fine wares from the Hardin A site are from bottles (see Tables 9 and 10). The few rims, possibly from Hickory Engraved bottles (Suhm and Jelks 1962:71) have sets of horizontal engraved lines at the top of the bottle neck. Decorative elements on bottle bodies include circle elements (with a central excised dot) with hatched and cross-hatched zones (Figure 7f), curvilinear lines (including one with small excised triangles, Figure 7d), diagonal opposed lines, curvilinear and diagonal hatched zones (Figure 7a,e), and distinctive bottle sherds with hatched pendant triangles (Figure 7b-c).

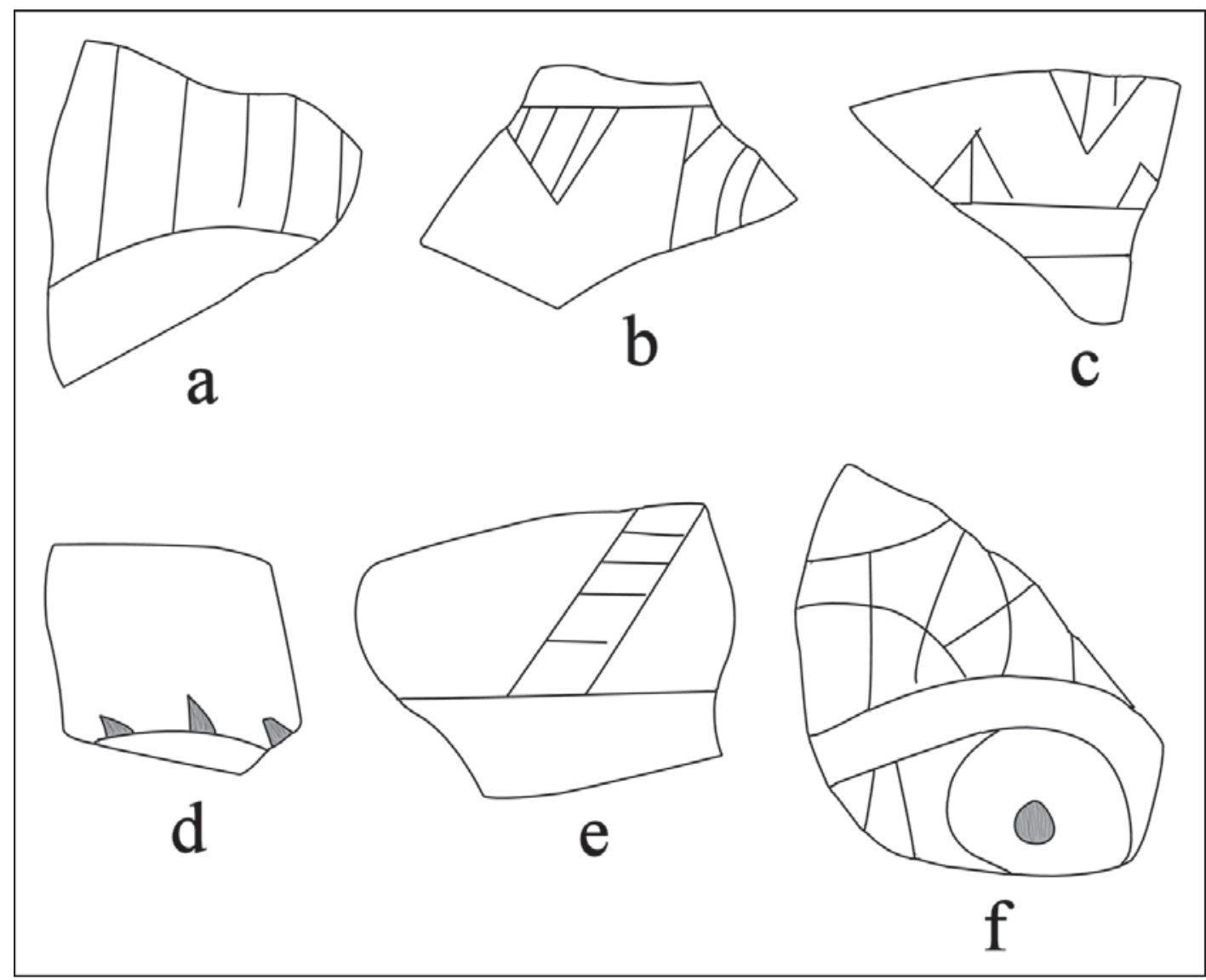

Figure 7. Decorative elements on engraved bottle sherds. Provenience: a, west side, surface; b, west side, surface; c, west side, surface; d, General, Area A; e-f, area around Unit 1.

Very few of the fine ware engraved sherds are from vessels where a clay pigment was rubbed in the engraved designs. Sherds with a red clay pigment comprise only 1.4 percent of the carinated bowl/bowl sherds and 4.5 percent of the bottle sherds. 


\section{Engraved-Appliqued}

A grog-tempered carinated bowl lower rim sherd from Unit $1(60-70 \mathrm{~cm}$ bs) has horizontal engraved lines above a horizontal appliqued ridge. Although this sherd is not from a bottle, an engraved-appliqued bottle was among the funerary offerings in Burial 5 in the Middle Caddo period cemetery at the Joe Smith site (41GG50) (Perttula and Nelson 2013:Figure 39).

\section{Red-slipped}

All three of the red-slipped sherds are grog-tempered body sherds (from the west side surface collection, Unit 1, 40-50 cm bs, and Unit 1, 140-150 cm bs) that have a hematite-rich slip on both interior and exterior surfaces; they are probably from carinated bowls. These sherds are from Sanders Plain vessels, as redefined by Brown (1996:401-403 and Figures 2-191, 2-34g, 2-37a-1, 2-38d, 2-39d, k, n-q, and 2-42b).

\section{CERAMIC PIPE SHERDS}

There are four pipe bowl rim sherds from long-stemmed Red River style pipes (see Hoffman 1967). They are from surface contexts. Three of the pipe bowl rims are from grog-tempered pipes, and the fourth bowl rim is from a bone-tempered pipe.

\section{RADIOCARBON DATES FROM THE SITE}

Two radiocarbon dates on charred hickory nutshells were obtained in 2001 from the Hardin A site, one from the midden deposits (50-70 cm bs) in Unit 1 (see Boyd and Perttula 2001:Figure 3), and the other from near the base of Feature 1 (140-150 cm bs). The calibrated radiocarbon age range from the midden sample is A.D. 1285-1445 at 2 sigma, with a cal A.D. 1405 intercept (Beta-143815). The calibrated radiocarbon age ranges of the charred nutshells in Feature 1 are A.D. 1315-1350 and A.D. 1390-1490 (2 sigma), with a cal A.D. 1425 intercept (Beta-143814). The two calibrated age ranges for the two samples overlap between A.D. 1315-1445, while the calibrated intercepts range from A.D. 1405-1425.

Six additional radiocarbon dates have been recently obtained from Direct-AMS on charred hickory nutshells from the archaeological deposits at the Hardin A site, three from different depths in the midden deposits (40-100 cm bs) and three from different depths in Feature 1 (100-140 cm bs) (Table 11). Calibrated using OxCal v4.2.3, the calibrated dates from the midden deposits are late 13th century A.D. in age, with median calibrated age ranges between A.D. 1273-1298 (Table 11 and Figure 8). The three calibrated dates from Feature 1 have mean calibrated ages between A.D. 1347-1352, with the highest probabilities associated with age ranges of A.D. 1337-1398 (0.58), A.D. 1298-1402 (0.95), and A.D. 1305-1365 (0.61) (Table 11). These six dates fall between the calibrated age ranges of the two previously obtained dates from the midden deposits and Feature 1.

Table 11. Recently obtained radiocarbon dates from the Hardin A site.

\begin{tabular}{|c|c|c|c|c|}
\hline $\begin{array}{l}\text { Lab No. } \\
\text { and Depth }\end{array}$ & $\begin{array}{l}\text { Conventional } \\
\text { Radiocarbon } \\
\text { age (B.P.) }\end{array}$ & $\begin{array}{l}1 \text { sigma } \\
\text { Calibrated } \\
\text { age range }\end{array}$ & $\begin{array}{l}2 \text { sigma } \\
\text { Calibrated } \\
\text { age range }\end{array}$ & $\begin{array}{l}\text { Median } \\
\text { calibrated age }\end{array}$ \\
\hline Midden & \multirow[b]{2}{*}{$734 \pm 26$} & \multirow[b]{2}{*}{$\begin{array}{l}\text { AD 1264-1284 } \\
(0.68)\end{array}$} & & \multirow[b]{2}{*}{ AD 1273} \\
\hline $\begin{array}{l}006759^{*} \\
40-50 \mathrm{~cm}\end{array}$ & & & $\begin{array}{l}\text { AD 1244- } \\
1294(0.94)\end{array}$ & \\
\hline
\end{tabular}


Table 11. Recently obtained radiocarbon dates from the Hardin A site, cont.

\begin{tabular}{|c|c|c|c|c|}
\hline $\begin{array}{l}\text { Lab No. } \\
\text { and Depth }\end{array}$ & $\begin{array}{l}\text { Conventional } \\
\text { Radiocarbon } \\
\text { age (B.P.) }\end{array}$ & $\begin{array}{l}1 \text { sigma } \\
\text { Calibrated } \\
\text { age range }\end{array}$ & $\begin{array}{l}2 \text { sigma } \\
\text { Calibrated } \\
\text { age range }\end{array}$ & $\begin{array}{l}\text { Median } \\
\text { calibrated age }\end{array}$ \\
\hline $\begin{array}{l}006760 \\
70-80 \mathrm{~cm}\end{array}$ & $711 \pm 23$ & $\begin{array}{l}\text { AD 1271-1290 } \\
(0.68)\end{array}$ & $\begin{array}{l}\text { AD 1261- } \\
1300(0.93)\end{array}$ & AD 1281 \\
\hline $\begin{array}{l}006761 \\
90-100 \mathrm{~cm}\end{array}$ & $672 \pm 19$ & $\begin{array}{l}\text { AD } 1283-1299 \\
(0.46), \text { AD } 1270- \\
1280(0.22)\end{array}$ & $\begin{array}{l}\text { AD 1278- } \\
1308(0.59), \\
\text { AD 1361- } \\
1387(0.36)\end{array}$ & AD 1298 \\
\hline \multicolumn{5}{|l|}{ Feature 1} \\
\hline $\begin{array}{l}006762 \\
100-110 \mathrm{~cm}\end{array}$ & $624 \pm 24$ & $\begin{array}{l}\text { AD 1299-1320 } \\
(0.27), \text { AD 1350- } \\
1371(0.26), \text { AD } \\
1379-1391(0.15)\end{array}$ & $\begin{array}{l}\text { AD 1291- } \\
1332(0.38), \\
\text { AD 1337- } \\
1398(0.58)\end{array}$ & AD 1352 \\
\hline $\begin{array}{l}006763 \\
110-130 \mathrm{~cm}\end{array}$ & $608 \pm 23$ & $\begin{array}{l}\text { AD 1304-1328 } \\
(0.28), \text { AD 1342- } \\
1365(0.27), \\
\text { AD 1384-1395 } \\
(0.13)\end{array}$ & $\begin{array}{l}\text { AD 1298- } \\
1402(0.95)\end{array}$ & AD 1348 \\
\hline $\begin{array}{l}006764 \\
130-140 \mathrm{~cm}\end{array}$ & $575 \pm 27$ & $\begin{array}{l}\text { AD } 1319-1351 \\
(0.44), \text { AD } 1391- \\
\text { AD } 1409(0.24)\end{array}$ & $\begin{array}{l}\text { AD 1305- } \\
1365(0.61), \\
\text { AD 1384- } \\
1419(0.34)\end{array}$ & AD 1347 \\
\hline
\end{tabular}

*Direct-AMS

In general, the calibrated radiocarbon dates obtained by Direct-AMS indicate with reasonable probability that the midden deposits at the Hardin A site began to accumulate in the late 13th century A.D. and probably continued to accumulate throughout much of the 14th century A.D. Feature 1, a large pit likely used for food storage, may have been excavated in the early years of the 14th century, and then it eventually was used as a receptacle for trash disposal (including the discard of charred hickory nutshells in the pit fill) around the mid-14th century A.D.

\section{SUMMARY AND CONCLUSIONS}

The Hardin A site is an ancestral Caddo habitation site in the middle reaches of the Sabine River basin in East Texas. Calibrated radiocarbon dates obtained on charred hickory nutshells from the archaeological deposits indicate that the site was first occupied by Caddo peoples in the latter part of the $13^{\text {th }}$ century A.D., and then was likely occupied by Caddo peoples throughout the $14^{\text {th }}$ century, during the Middle Caddo period.

In addition to four long stemmed Red River pipe sherds, the Hardin A site has a substantial assemblage of plain ware ( $n=1535)$, utility ware $(n=474)$, and fine ware $(n=96)$ sherds; most of the sherds are from surface collections, although about 24 percent of the utility wares and fine wares are from Unit 1 and 2 excavations. 


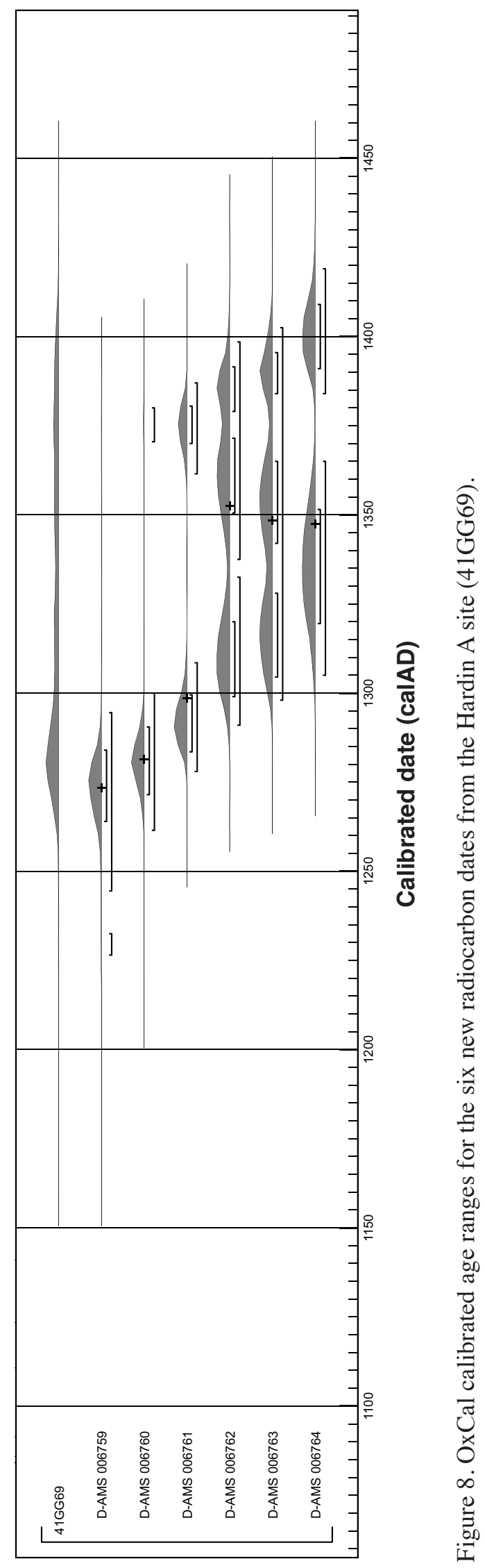


The ancestral Caddo ceramic sherd assemblage at the Hardin A site is primarily grog-tempered, as 85.6 percent of the sherds are tempered with crushed sherds (Table 3). Only 14.4 percent of the sherds are from vessels tempered with burned bone, and there are no shell-tempered sherds in the assemblage.

The utility ware sherds are from jars, likely used for food storage and cooking activities. The principal utility ware decorative methods in the sherds from the Hardin A site are incised (29 percent), incised-punctated (26 percent), brushed (16 percent), and tool punctated (15 percent). Considering just the rim sherds, 8 percent are from brushed and brushed-punctated vessels; 37 percent are from incised vessels; 25 percent are rims from incised-punctated vessels; and 27 percent are from vessels with either circular, fingernail, or tool punctations on the rim. Ceramic types recognized in the utility ware sherds include Bullard Brushed, Canton Incised, Davis Incised, Dunkin Incised, Crockett Curvilinear Incised, Pennington Punctated-Incised, Pease Brushed-Incised, and Killough Pinched. One sherd of Belcher Ridged in the assemblage suggests that the site was used to a limited extent as late as ca.A.D. 1500 and after, based on the dates on sites with Belcher Ridged pottery in the Red River basin in Northwest Louisiana.

Fine ware sherds from bowls, bottles, and carinated bowls only comprise 17 percent of the decorated sherds in the Hardin A ceramic assemblage. The most common decorative elements in the engraved rim and body sherds from carinated bowls and bowls include sets of curvilinear lines (17 percent) and horizontal lines in association with cross-hatched, curvilinear, diagonal, diagonal opposed, and semi-circular lines (16 percent). Other important elements include sets of parallel engraved lines (14 percent), probably either horizontal or diagonal in orientation, diagonal and diagonal opposed lines ( 9 percent), sets of horizontal lines (9 percent), and horizontal lines in association with hatched or cross-hatched zones (9 percent). Most of these sherds cannot be linked with defined East Texas Caddo ceramic types, but there are a few sherds from Holly Fine Engraved vessels. Engraved bottle rims may be from Hickory Engraved bottles. Decorative elements on bottle bodies include circle elements (with a central excised dot) with hatched and cross-hatched zones, curvilinear lines (including one with small excised triangles), diagonal opposed lines, curvilinear and diagonal hatched zones, and distinctive bottle sherds with hatched pendant triangles. The few red-slipped sherds are from Sanders Plain carinated bowls.

In sum, the well-dated Caddo occupation at the Hardin A site provides an excellent temporal context (late 13th century A.D. throughout the 14th century A.D.) for understanding the technological and stylistic character of middle Sabine River basin ceramic assemblages during the Middle Caddo period, as do nearby habitation areas and cemeteries at 41GG5 and the Joe Smith site (41GG50). These sites are part of a community of ancestral Caddo peoples that lived along the Sabine River and its tributaries, and they were contemporaneous with better known Middle Caddo sites in the Pine Tree Mound community defined by Fields and Gadus (2012:Figure 9-10) some 25-40 km downstream in the Sabine River basin - which was established in the A.D. 1300s - but the differences in the ceramics between the two areas suggest that the Hardin A, 41GG5, and Joe Smith sites were not part of that community.

\section{ACKNOWLEDGMENTS}

I would like to thank Bryan Boyd for his permission to analyze his collections from the Hardin A site, and for his willingness to donate his collections from the site to the Texas Archeological Research Laboratory at The University of Texas at Austin. Lance Trask prepared Figures 1-7 for this article. Dr. Robert Z. Selden Jr. provided the OxCal 2013 calibrations of the six recently obtained radiocarbon dates from the site as well as Figure 8. 


\section{REFERENCES CITED}

Boyd, B. E. and T. K. Perttula

2001 Initial Findings from the Archeological Investigations of the Hardin A Site (41GG69), Gregg County, Texas. Caddoan Archeology 12(1):5-10.

Brown, J. A.

1996 The Spiro Ceremonial Center. The Archaeology of Arkansas Valley Caddoan Culture in Eastern Oklahoma. 2 Vols. Memoir No. 29. Museum of Anthropology, University of Michigan, Ann Arbor.

Dockall, J. E. and R. C. Fields

2011 National Register Testing of Three Sites in the Sabine Mine's South Hallsville No. 1 Mine-Rusk Permit, Rusk County, Texas. Report of Investigations No. 162. Prewitt and Associates, Inc., Austin.

Dockall, J., S. Katauskas, and R. Fields

2008 National Register Testing of Four Sites in the Sabine Mine's Area M, Harrison County, Texas. Reports of Investigations No. 157. Prewitt and Associates, Inc., Austin.

Dunnell, R. C.

1978 Style and Function: A Fundamental Dichotomy. American Antiquity 43(2):192-202.

Fields, R. C. and E. F. Gadus (editors)

2012 Archeology of the Nadaco Caddo: The View from the Pine Tree Mound Site (41HS15), Harrison County, Texas. 2 Vols. Reports of Investigations No. 164. Prewitt and Associates, Inc., Austin.

Gadus, E. F., R. C. Fields, J. K. McWilliams, J. Dockall, and M. C. Wilder

2006 National Register Testing of Seven Prehistoric Sites in the Sabine Mine's Area Q, Harrison County, Texas. Reports of Investigations, Number 147. Prewitt and Associates, Inc., Austin.

Girard, J. S.

2007 Byram Ferry (16BO17): A Middle to Late Caddo Period Mound Site in the Red River Floodplain, Northwest Louisiana. Caddo Archeology Journal 16:9-25.

Heartfield, Price, and Greene, Inc.

1988 Data Recovery at 41HS74, Harrison County, Texas. Heartfield, Price, and Greene, Inc., Monroe.

Hoffman, M. E.

1967 Ceramic Pipe Style Chronology Along the Red River Drainage in Southwestern Arkansas. The Arkansas Archeologist 8(1):4-14.

Perttula, T. K.

2015 East Texas Caddo Ceramic Sherd Database. Journal of Northeast Texas Archaeology 51, in press.

Perttula, T. K. and B. Nelson

2013 Two Middle Caddo Period Habitation Sites and Cemeteries in the Sabine River Basin, Gregg County, Texas. Special Publication No. 27. Friends of Northeast Texas Archaeology, Pittsburg and Austin.

Schniebs, L.

2014 Analysis of the Hardin A Site (41GG69) Faunal Remains. Journal of Northeast Texas Archaeology 47:9-15.

Suhm, D. A. and E. B. Jelks (editors)

1962 Handbook of Texas Archeology: Type Descriptions. Special Publication No. 1, Texas Archeological Society, and Bulletin No. 4, Texas Memorial Museum, Austin. Reprinted in 2009, Gustav's Library, Davenport, Iowa. 